\author{
BOLESŁAW DOMAŃSKI \\ Jagiellonian University, Krakow, Poland \\ KRZYSZTOF GWOSDZ \\ Jagiellonian University, Krakow, Poland
}

\title{
Changing Geographical Patterns of Automotive Industry in Poland
}

\begin{abstract}
The paper aims at identifying the main trends in the spatial patterns of automotive industry in Poland and their underlying changes. The analysis includes the distribution of employment in the sector by regions (voivodeships) in 1998 and 2015 on the basis of the Central Statistical Office data, as well as the location of greenfield plants built in the country since 1991 using the authors' database. It is shown that after the general stability of the spatial pattern of production in the first transformation phase of the 1990s, a major shift towards south-western and western Poland together with the decline of the historically dominant region of Warsaw took place later. This can be explained by the success and/or decline of some leading producers and trends in the location of new plants dependent on the proximity to foreign markets, good road accessibility and industrial traditions (labour skills) in the main. These tendencies are in congruence with the general changes in the spatial pattern of Polish industry as a whole, with the growing role of Wielkopolskie and Dolnośląskie voivodeships and the decreasing share of Mazowieckie in the national industrial employment. The rapid expansion of automotive industry in Upper Silesian Industrial District has contributed to its successful restructuring.
\end{abstract}

Keywords: automotive industry; geographical pattern; Poland; spatial changes

Received: 9 May 2018

Accepted: 1 August 2018

\section{Suggested citation:}

Domański, B., Gwosdz, K. (2018). Changing Geographical Patterns of Automotive Industry in Poland. Prace Komisji Geografii Przemystu Polskiego Towarzystwa Geograficznego [Studies of the Industrial Geography Commission of the Polish Geographical Society], 32(4), 193-204. https://doi.org/10.24917/20801653.324.12

\section{INTRODUCTION}

Post-socialist transformation brought about fundamental changes in Central European manufacturing. State ownership was replaced by private enterprises and Eastern European markets largely by the Western European ones, which was accompanied by the reshaping of organisation, technology, productivity and employment. The dynamics and attributes of these processes differed among various sectors leading to significant changes in the sectoral structure of manufacturing. The interesting question is to what 
extent these radical restructuring resulted in a shift in geographical distribution of production and employment.

The issue of the geographical change of industrial activity can be approached in the evolutionary theoretical perspective. On the one hand, the privileged position of the developed regions based on agglomeration economies could be expected. Among other advantages, they might benefit from the established market position and supplier networks of large firms, as well as possible spinoffs. Moreover, foreign investors, which have become important forces of the growth of Central European economies since 1989, often tend to locate in the advanced areas of emerging countries, the capital region in particular, rather than in peripheral regions, due to easier availability of information and lower uncertainty (Dicken, 2015). On the other hand, the development of old industrial districts may be hindered by negative mechanisms of lock-in, as a result of overspecialisation, oligopolistic economic structures and/or institutional sclerosis and rigidification (Hudson, 1989; Grabher, 1993; Hassink, 2010). Their situation may be exacerbated by their negative image of areas of unfavourable environmental and social conditions, including strong unions and high wages. In addition, institutional approach may be useful here to capture the role of public authorities in the processes of regional change.

The authors address the problem of changing spatial patterns of automotive industry in Poland. The aim is to identify the main trends in this respect and the factors underlying the regional and local changes.

The automotive sector seems particularly suitable to address these questions due to its fast expansion in Poland and in Central Europe in general in the last two decades, as well as vast domination of foreign-owned companies (Domański, Guzik, Gwosdz, Dej, 2013). It is a prominent sector of high-volume production including both sophisticated components and relatively simple labour-intensive ones. The share of the automotive industry (NACE 29) in the total sold production of Polish manufacturing and mining has increased from $2.4 \%$ in 1991 to $10.7 \%$ in 2016 (6.7\% in value added and $6.2 \%$ in employment of national industry). The broadly defined sector provides about 20 per cent of Poland's exports and contributes to an increasing trade surplus in manufactured goods with core economies of Western Europe.

The development of the automotive sector or passenger car industry in Poland from the spatial perspective has been analysed earlier by K. Gwosdz and G. Micek (2010), P. Lizak (2011) and P. Nowak (2011). There are several studies on the geographical change in other manufacturing sectors in Poland, most of them illustrate moderate changes in spatial structures, e.g. in fish processing industry (Czapliński, 2013), furniture production (Dyba, 2017) and brewing industry (Wojtyra, Grudzień, 2017), but some reveal more radical shift, e.g. in footwear manufacturing (Kocaj, 2016). This can be seen in a broader context of changing patterns of the transition of Polish economy (Stryjakiewicz, 2009), foreign investment in the country (Tobolska, 2014), the impact of changing spatial accessibility (Komornicki, Rosik, Śleszyński, Solon, Wiśniewski, Stępniak, Czapiewski, Goliszek, 2013) and the multiplier effects of the supplier networks of large firms (e.g. Wiedermann, 2006; Stryjakiewicz, 2008).

The paper is divided into four main sections. First, the distribution of employment in automotive industry by regions (voivodeships) in 1998 and 2015 is examined with shift-share analysis on the basis of the Central Statistical Office data on the narrowly defined automotive industry (NACE 29). Then the analysis of the location of greenfield 
plants built in the country since 1991 is carried out using the authors' database covering broadly understood automotive sector, including NACE 29 together with the producers of auto components classified in other branches, especially seats, electric, plastic and rubber parts. This is followed by the explanation of the identified trends and conclusions with comparison to trends in other countries and Polish manufacturing in general.

\section{REGIONAL DIFFERENTIATION OF THE SECTOR 1998-2015}

When state socialism ended there were two major concentrations of the automotive industry in the country: in the capital region of Warsaw in central Poland and in the Upper Silesian Industrial District with Bielsko-Biała area in the south. The former represented the historical core of the sector, which began with assembly activities before World War II and grew following the establishment of FSO in 1950 with numerous branch plants and component suppliers in the region. The latter was largely a product of the creation of FSM in 1971 with an engine factory in Bielsko-Biała, the car assembly plant in Tychy and about a dozen branch plants. There were also two truck plants (Starachowice and Lublin) and a bus factory (Sanok) in the south-east of the country, as well as smaller ones in western Poland (Jelcz, Nysa, and Poznań), but they were not accompanied by a large number of suppliers.

Fiat was the first international carmaker that decided to invest in Poland acquiring FSM in 1992. It was followed by Daewoo Motors, which bought the Warsaw-based FSO and Lublin light truck plant in 1996, while VW started to expand a small light vehicle factory in Poznań in 1993. In 1998 a new greenfield car assembly plant was opened by General Motors in Gliwice in Upper Silesia. Truck and bus factories were chiefly privatised by domestic capital, new bus assembly plants were located by Volvo in Wroclaw and MAN near Poznań. Major foreign supplier companies, including Delphi and Valeo, gradually increased their investment in the country taking over state-owned producers and/or building new factories (Domański, 2001).

Despite considerable ownership shift, the geographical picture of the automotive industry in the late 1990s was more or less the same as a decade earlier. More than $40 \%$ of employment in the sector in 1998 was concentrated in two regions: Śląskie (22.4\%) and Mazowieckie (18.1\%), and nearly two-thirds in four voivodeships including Podkarpackie (11.7\%) and Wielkopolskie (10.7\%). The decline of the Starachowice truck plant resulted in the lower position of Świętokrzyskie.

The rapid growth of production, fuelled primarily by vast foreign investment, led to a systematic increase in the number of people working in the automotive industry in Poland since 1998. By 2015 the employment in the narrowly defined automotive sector (NACE 29) has risen from 100,600 to 177,100 people. In absolute terms, the largest growth in employment took place in Śląskie $(+31,800)$, followed by Dolnośląskie $(+22,700)$, Wielkopolskie $(+11,900)$ and Lubuskie $(+9,700)$. The shift-share analysis confirms the enhanced role of south-western regions of Dolnośląskie $(+9.4$ percentage points) and Śląskie (+8.3) along with western voivodeships of Lubuskie and Wielkopolskie, and partly Małopolskie. On the other hand, a spectacular decline occurred in the share of the central region of Mazowieckie ( -14.3 percentage points), and to somewhat lesser extent in the case of Lubelskie and Podkarpackie in the south-east (Fig. 1). 
Fig. 1. Shift-share in the employment in automotive industry (NACE 29) in Poland, 1998-2015 (changes in the share of voivodeships in the national employment in the automotive industry)

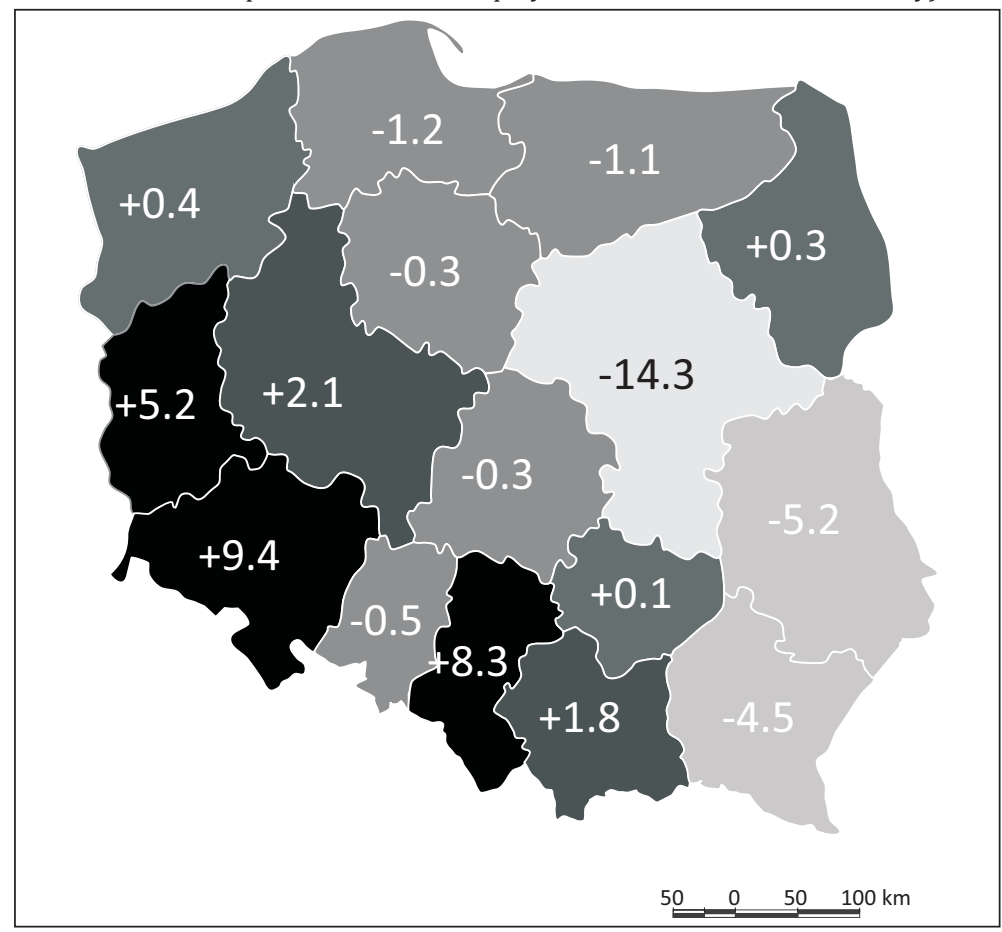

Source: authors' work based on the Central Statistical Office data

Mazowieckie and Lubelskie have experienced an absolute loss of employment, whereas the number of jobs in Podkarpackie has increased, but at a lower rate than nationally.

Thus, the spatial distribution of the automotive industry in 2015 differs significantly from the situation in the first decade of post-socialist transformation. There is a strong agglomeration of the sector in south-western Poland with the new core in Śląskie voivodeship, including Upper Silesian conurbation, Bielsko-Biała subregion and Częstochowa. Its share in the national employment has increased to $30.7 \%$, and the share of Dolnośląskie to $17.3 \%$, hence these two voivodeships concentrate almost half of the workforce of the Polish automotive industry. Wielkopolskie represents $12.8 \%$ of the employment in NACE 29. Five voivodeships of south-western and western Poland together with Lubuskie and Opolskie comprise $70 \%$ of this employment. The marked specialisation of these regions in the automotive industry is illustrated by the location quotient comparing the share of employment in NACE 29 sector and the share of working age population. Such location quotient is the highest in Śląskie, Dolnośląskie and Lubuskie, and above average in Wielkopolskie, Opolskie and Podkarpackie (Fig. 2). Despite the relatively slower growth since 1998, Podkarpackie shows the fourth largest workforce in the sector (7.2\%), and three south-eastern voivodeships including Małopolskie and Świętokrzyskie represent $16 \%$ of the national employment. Lubelskie is no longer important here, and the share of Mazowieckie is merely 3.8\% now. 
Fig. 2. Location quotient of the employment in automotive industry (NACE 29) in relation to the working age population in Poland in 2015

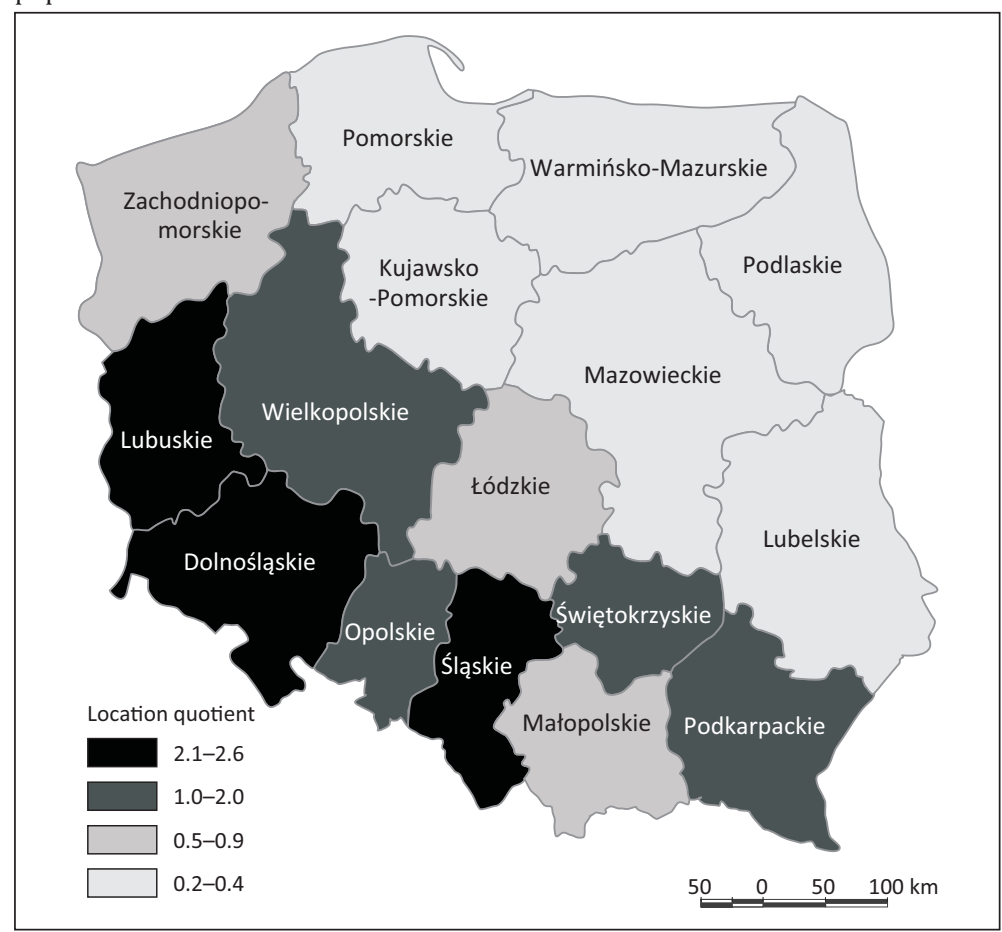

Source: authors' work based on the Central Statistical Office data

\section{LOCATION OF GREENFIELD PLANTS SINCE 1991}

What deserves special attention from the geographical point of view is the location of new plants. There are 325 greenfield factories manufacturing motor vehicles and their components that opened in Poland between 1991 and 2016. Fig. 3 shows that their spatial distribution is extremely uneven (Fig. 3).

By far the largest concentration of new automotive plants is found in Śląskie - in the historical Upper Silesian Industrial District and the Bielsko-Biała area to the south. Substantial greenfield investment in the sector has been attracted by Dolnośląskie, where it is located both in the Wrocław metropolitan area as well as in Legnica-Polkowice subregion to the west and the Sudeten to the south. Large and medium-sized factories have also been built in Wielkopolskie, Lubuskie and Opolskie.

Greenfield investment outside south-western and western regions have been relatively rare. Some of it has taken place in Małopolskie and Podkarpackie in the southeast as well as in Mazowieckie and Łódzkie in central Poland, but very few in other areas of eastern and northern parts of the country.

It is interesting to examine the location of greenfield plants opened in three periods: 1991-1998, 1999-2006 and 2007-2016, i.e. after the financial crises (Fig. 4). South-western and western regions have been attractive places for the location of new factories from the early years of the transformation until nowadays. This is also to a lesser extent true about Podkarpackie in the south-east. Greenfield investment in Małopolskie started at 
Fig. 3. Location of new plants in automotive industry in Poland, 1991-2016 (size of employment in 2016)

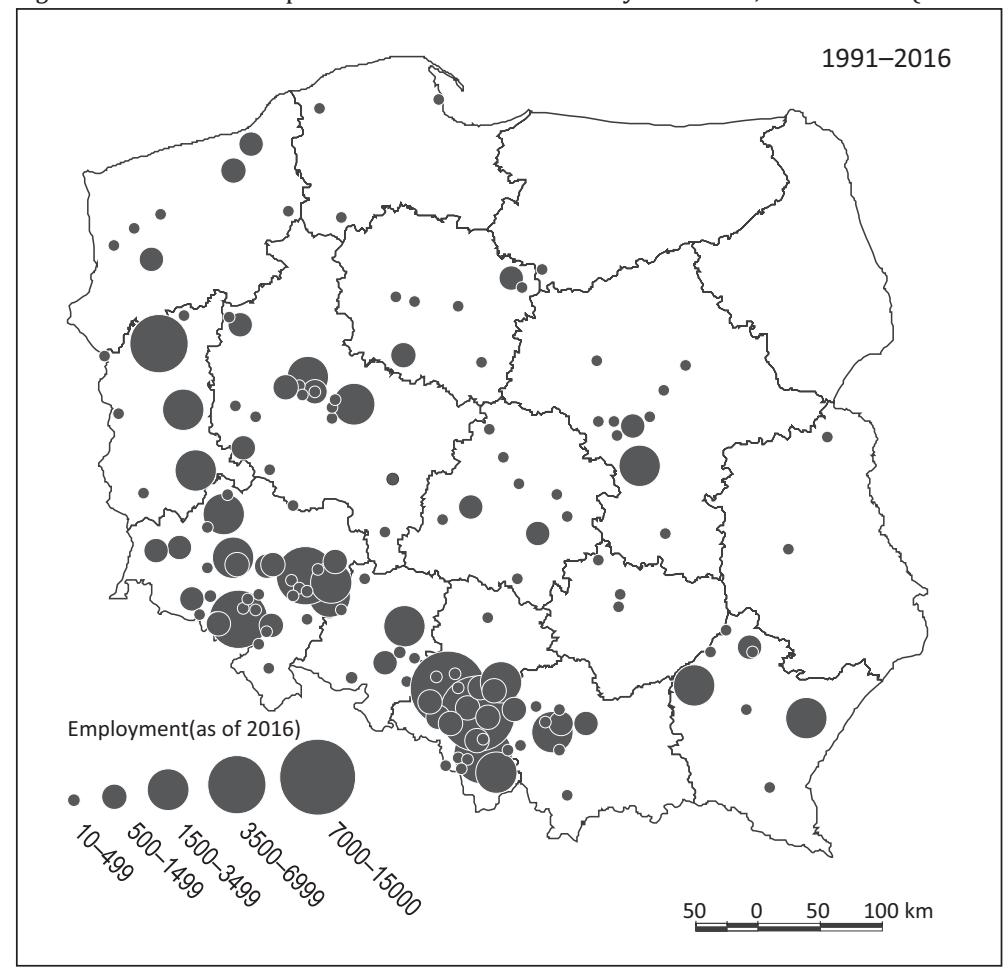

Source: authors' work

Fig. 4. Location of new plants in automotive industry in Poland, 1991-1998, 1999-2006 and 2007-2016 (size of employment in 2016)

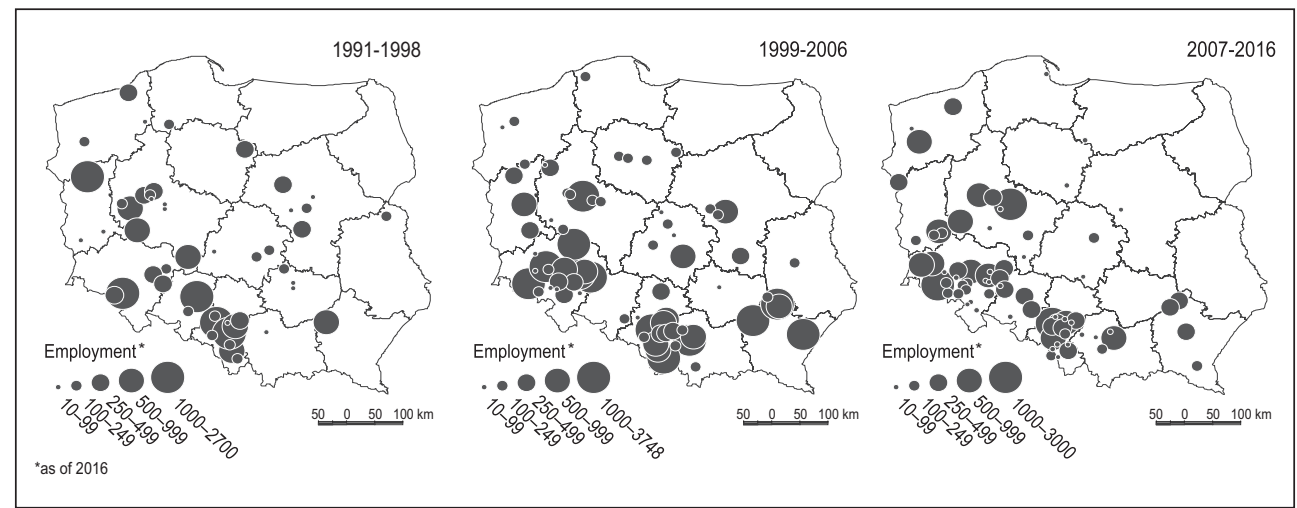

Source: authors' work

the end of the 1990s. By contrast, automotive plants were built in the central regions of Mazowieckie and Łódzkie in the 1990s and at the beginning of the 21st century, but this is no longer the case in the recent decade. The trend to locate factories in south-western and western parts of Poland has never been so dominant as since 2007, when almost no companies chose central and eastern Poland, except for Podkarpackie. 


\section{FACTORS AFFECTING THE GEOGRAPHICAL SHIFT IN POLISH AUTOMOTIVE SECTOR}

After little change in the spatial pattern of the automotive industry in Poland in the 1990 s, a major geographical shift took place in the 21st century. It stems, on the one hand, from the successful development or decline/closure of some large existing producers and, on the other, from the trends in the location of new plants.

The early privatization of FSM and the modernisation and expansion of car and engine production by Fiat together with the advent of its Italian suppliers strengthened the position of the Upper Silesian and Bielsko-Biała region. This increased its attractiveness for the greenfield investment of various component producers ${ }^{1}$, which was further boosted by the location of a new General Motors assembly plant, and is discussed in detail later. A similar process to some extent took place in Wielkopolskie with a gradual development of van production by Volkswagen in Poznań.

At the same time, Daewoo Motors, which had become the owner of FSO, ran into financial trouble after the Asian crisis in the late 1990s, went bankrupt and was sold to GM, but its overseas subsidiaries were not part of the deal. FSO became controlled by the Ukrainian carmaker UkrAVTO and finally stopped car assembly in 2011. As a consequence, the manufacturing of automotive components in the Warsaw region has also significantly decreased and some of the suppliers shifted to other production.

In addition, the collapse of Daewoo resulted in the bankruptcy of the van producer in Lublin in 2001. Moreover, Zasada Group was not able to maintain the position of truck and bus manufacturers in south-eastern Poland; hence the role of this region in the sector has been diminished. The Starachowice factory was taken over by MAN in 1999 and specialises in the production of bus frames now ${ }^{2}$, the Sanok plant is again state-controlled after its bankruptcy in 2013.

The large number of new factories built in Poland since 1991 had a vital impact on the contemporary geographical picture of the industry. Three fundamental factors seem to have determined their location: the position in relation to the market (customers), geographical road accessibility and the availability of skilled labour.

The automotive industry is characterised by the extensive network of suppliers and deliveries are increasingly made on a just-in-time basis, i.e. they arrive at the assembly plant shortly before they are needed in order to reduce the costs of inventory. To facilitate the reliability of such deliveries the majority of suppliers are located within a one-day driving distance from their customers, which means up to 700-800 km (Klier, Rubenstein, 2010). In the situation when automotive components made in Poland are primarily exported to Western Europe, Germany, Italy and France in the first place, eastern and northern regions of the country are at a disadvantage. Furthermore, the dynamic development of the automotive industry in Poland is part of its growth in the broader Central European agglomeration. Numerous plants located and expanded in south-western Poland are suppliers of factories situated nearby in the Czech Republic, newly-built assembly plants in Slovakia, as well as automotive producers in Hungary.

\footnotetext{
${ }^{1}$ Determinants and effects of the development of automotive industry in Śląskie voivodeships were examined by Wiedermann (2006)

${ }^{2}$ In 2016 MAN relocated production of city buses from Sady near Poznań and coaches from Salzgitter to Starachowice, increasing employment.
} 
A favourable location in relation to customers as well as various suppliers is connected with good geographical accessibility of a factory. As most transportation goes by road this means a privileged position of areas with modern motorways. There is little doubt that the early construction of the A4 motorway as the first motorway in the country, linking Lower and Upper Silesia with Germany and further with the European road network, was instrumental in attracting numerous new factories in these regions. Its eastern extension made Podkarpackie voivodeship the only region of eastern Poland with significant greenfield investment. The A2 motorway is important for the location of new plants in Wielkopolskie and Lubuskie, while the motorway A1 improved the connections of Śląskie with the Czech Republic, Slovakia and Italy.

Quality requirements in the automotive sector are particularly high. It is evident that most greenfield investment was located in towns and regions with industrial history, where technical culture and skilled manufacturing labour could be found. This is true of south-western and western regions, but also Podkarpackie due to the traditions of the Central Industrial District dating back to the 1930s.

The role of the public sector and policies is interesting in this context. There are two mechanisms how it could affect the location of new factories. First, the establishment of early special economic zones in the 1990s, when only limited areas offered tax exemptions and infrastructural advantages, was important in the case of Upper Silesia, Podkarpackie and partly Lower Silesia. Second, the pro-investment attitude and activity of local authorities mattered. This could have a self-reinforcing effect due to the learning process in the communes which were successful in attracting an investor and developed their competences in meeting the expectations of further firms.

Last but not least, there is clear imitation behaviour in locational choices of foreign investors. This is illustrated by the fact that there are more than ten or even twenty automotive plants of various firms situated in a single town, e.g. Gliwice, Bielsko-Biała, Wałbrzych, most of which are not connected by direct supply linkages. The choice of a place where other manufacturers have invested earlier may depend on serving the same customer, but may also stem from favourable infrastructural conditions created by the local authorities and lower uncertainty related to the presence of other firms. In addition, companies often choose location of a new factory in the same region where they already have production facilities, e.g. Toyota, Faurecia, Tenneco, which is associated with their knowledge about the area and allows better management and possibly workforce transfer.

All things considered, western and especially south-western Polish regions offer the best conditions for the location of new automotive plants: proximity to the major foreign markets, good accessibility and skilled labour. Their attractiveness for the component manufacturers has been enhanced by the location of the GM car assembly plant in Gliwice, new bus factories of Volvo in Wrocław and Solaris and MAN near Poznań, as well as the expansion of existing car plants in Tychy and Poznań. The immense greenfield investment has not been discouraged by the traditions of strong trade unions and environmental problems characteristic of old industrial regions such as Upper Silesia and the Sudeten. Together with the development of existing plants this contributed to their current dominant position in the automotive sector of the country, even though two important final producers from the socialist era lost their significance - the Nysa van plant went bankrupt and the state-owned Jelcz company remains a small-scale manufacturer of military trucks. 
The loss of the leading role in the discussed industry by the Warsaw region is an effect of the collapse of the foreign investor which controlled the core company. What is harder to explain is the limited greenfield investment in Mazowieckie, and in central Poland in general. This may be related to a relatively late motorway connection, high costs of land in the fast growing metropolitan area of the capital city (Gwosdz, Micek, 2010), possibly insufficient supply and high costs of industrial labour force and lower maximum regional aid intensity than in other regions. The development of the sector in Łódzkie was similar to the national trend. One of few large domestic-owned automotive manufacturers is situated here - Wielton established in Wieluń in 1996 has become one of the top European producers of semi-trailers and trailers.

Świętokrzyskie has retained its position, despite lower employment in the Starachowice factory and very little greenfield investment. In contrast, several large and medium-sized new plants were located in Podkarpackie due to its industrial labour supply, good connection through the A4 motorway and possibly higher regional aid intensity than in western regions, but the region has suffered from the difficulties of the Sanok bus factory.

It has to be emphasized that if we take into account a broadly defined automotive sector, including components classified outside NACE 29, the picture of the industry in some regions may be different. There are for example a tyre plant in Dębica and a factory of rubber components in Sanok in Podkarpackie, another large tyre producer is situated in Olsztyn in Warmińsko-Mazurskie in the north-east and several manufacturers of plastic parts are located in Kujawsko-Pomorskie and Łódzkie.

There is some evidence of the functional division between metropolitan areas and higher developed regions of Upper and Lower Silesia and Wielkopolskie on the one hand and eastern Poland including Podkarpackie on the other. More sophisticated higher-value added products seem to be manufactured in the former, while the latter tend to specialise in more simple, labour-intensive ones. The issue is worth broader analysis and discussion as the specialisation in various types of products may affect the future prospects of individual industrial towns and regions.

\section{CONCLUSION}

The time of the dynamic growth of Polish automotive industry is a period of a major shift in the spatial distribution of production, which began in the late 1990s. The radical change in the geography of the sector results from both massive foreign greenfield investment in south-western and western regions and the collapse of some companies foreign investors such as Daewoo and former state-owned monopolistic manufacturers of buses and heavy vehicles. Thus, this geographical change can be seen as a product of globalization and its relations with local conditions and processes including post-socialist transformation.

The Upper Silesian Industrial District together with the neighbouring Bielsko-Biała, and partly Częstochowa and Krakow regions have developed as the core of the sector in the country with two car assembly plants, diversified supplier base and relatively strong non-production functions including R\&D. The emergence of this new core area can be seen as a path-dependent process, the seeds of which were sown by locational decisions related to Fiat-licensed car in the 1970s, its early successful privatisation and the location of General Motors, which have triggered large foreign investment in the 
area. Dolnośląskie is a major winner of the expansion of automotive component sector in the corridor of the A4 motorway close to German and Czech borders. Proximity to foreign markets, good road accessibility, industrial traditions (skills), infrastructure and special economic zone incentives are important factors behind the location of numerous new plants in south-western and western Poland, as well as to some extent in Podkarpackie. Institutional factors in the form of national policy together with attitudes and activity of local governments proved important to attract foreign corporations to industrial towns and regions and hence trigger the agglomeration processes fuelled later by imitation locational behaviour of further investors.

All this means that the advantages of industrial regions and towns prevailed. Foreign investors have not been discouraged by their structural and social legacy and negative image, and hence contributed to their structural change.

The study confirms the growing spatial concentration of automotive industry in Poland, which leads to the creation of a few strong agglomerations with a large number of producers embedded in extensive supplier networks. K. Gwosdz and G. Micek (2010) identified hub-and-spoke and TNC-led satellite platforms as the most frequent agglomeration types in the sector, but no Porter's clusters nor Marshallian industrial districts. As to the mechanisms of the spatial evolution of the automotive industry, agglomeration economies have been important in the formation of its structure in Poland, while rather limited role has been played by spinoff processes emphasized by Boschma and Wneting (2007) in the case of the Coventry-Birmingham region in the United Kingdom.

The surprising demise of the historically leading role of the Warsaw region, contrasting with the locational preference of foreign investors for the capital regions of many countries, general trends of the inflow of capital to the Warsaw metropolitan area and its fast economic growth since the 1990s, is contingent on individual events.

A significant change in the spatial pattern of Polish automotive industry contrasts with the general continuity in its geographical distribution in many countries. For example, Hardi et al. (2014) point out that foreign export-oriented investment in Romania and Serbia has contributed to the development of the major clusters of the automotive industry formed in the past, outside the capital cities. The motor vehicle industry in the United States remains largely concentrated in the vast region called auto alley extending between the Great Lakes and the Gulf of Mexico. However, auto alley was only formed in the 1980s, whereas earlier most of automotive component production was concentrated in the much narrower area of the Central Manufacturing Belt between Milwaukee and Buffalo with the core in south-eastern Michigan (Klier, Rubenstein, 2010).

Finally, it is worth noting that the identified trends in the geographical distribution of the automotive sector are in congruence with the general changes in the spatial pattern of Polish industry as a whole. Wielkopolskie and Dolnośląskie are two regions which have increased their share in the national industrial employment most of all since 1998, the role of Lubuskie has also risen. All these voivodeships have shown the fastest growth in value added in industry. The enhanced position of the historically industrialised regions of Wielkopolskie and Dolnośląskie has been emphasized earlier by T. Rachwał (2010) and B. Domański (2015). At the same time, the share of Mazowieckie in the industrial employment in Poland has decreased; its dynamic GDP growth by and large rests on the development of the service sector. The main difference concerns Śląskie as its general industrial growth rate was below the national average and its share in the national employment has lowered. This reflects the shrinking of the traditional sectors 
such as coal mining and metal industries in the Upper Silesian Industrial District, where the rapid expansion of automotive industry has become an important factor of the successful restructuring.

\section{References}

Boschma, R., Wneting, R. (2007). The spatial evolution of the British automobile industry: Does location matter? Industrial and Corporate Change, 16(2), 213-238.

Czapliński, P. (2013). Formowanie się nowej struktury przestrzennej przemysłu przetwórstwa rybnego w Polsce [Creating a New Spatial Structure of Fish Processing Industry in Poland]. Prace Komisji Geografii Przemysłu Polskiego Towarzystwa Geograficznego [Studies of the Industrial Geography Commission of the Polish Geographical Society], 21, 121-132.

Dicken, P. (2015). Global shift: mapping the changing contours of the world economy. London: Guilford Press.

Domański, B. (2001). Kapitał zagraniczny w przemyśle Polski [Foreign capital in the Polish industry]. Kraków: Instytut Geografii i Gospodarki Przestrzennej Uniwersytetu Jagielloński.

Domański, B. (2015). Współczesne procesy przemian regionalnych przemysłu Polski [Contemporary processes of regional industrial changes in Poland]. Prace Komisji Geografii Przemysłu Polskiego Towarzystwa Geograficznego [Studies of the Industrial Geography Commission of the Polish Geographical Society], 29(4), 40-53.

Domański, B., Guzik, R., Gwosdz, K., Dej, M. (2013). The crisis and beyond: the dynamics and restructuring of automotive industry in Poland. International Journal of Automotive Technology and Management, 13(2), 151-166.

Dyba, W. (2017). Klastry meblarskie na tle struktury przestrzennej przemysłu meblarskiego w Polsce [Furniture Clusters in the Spatial Structure of the Furniture Industry in Poland]. Prace Komisji Geografii Przemysłu Polskiego Towarzystwa Geograficznego [Studies of the Industrial Geography Commission of the Polish Geographical Society], 31(1), 38-51.

Grabher, G. (1993). The weakness of strong ties: the lock-in in regional development in the Ruhr Area. In: G. Grabher (ed.). The embedded firm. On the socioeconomics of industrial networks. London: Routlege, 255-277.

Gwosdz, K., Micek, G. (2010). Spatial agglomerations in the Polish automotive industry. Przeglad Geograficzny, 82(2), 159-190.

Hardi, T., Mladenov, C., Kazakov, B., Miklósné Zakar, A., Nagy, I., Kralovacski, Á. (2014). The evolution of passenger car production and its impact on urban development in South-Eastern Europe. In: S. Pfeil (ed.). Industrial districts and cities in Central Europe. Győr: UniversitasGyőr Nonprofit Ltd, 89-108.

Hassink, R. (2010). Locked in decline? On the role of regional lock-ins in old industrial areas. In: R. Boschma, R. Martin (ed.). The handbook of evolutionary economic geography. Cheltenham: Edward Elgar, 450-468.

Hudson, R. (1989). Wrecking a region: state policies, party politics and regional change in North East England. London: Pion.

Klier, T., Rubenstein, J. (2010). The changing geography of North American motor vehicle production. Cambridge Journal of Regions, Economy and Society, 3, 335-347.

Kocaj, A. (2016). Understanding the transformation of the Polish footwear industry through firm's strategies, trade geography and spatial heritage. Zeitschrift für Wirtschaftsgeographie, 60(4), 186-200.

Komornicki, T., Rosik, P., Śleszyński, P., Solon, J., Wiśniewski, R., Stępniak, M., Czapiewski, K., Goliszek, S. (2013). Impact of the construction of motorways and expressways on socio-economic and territorial development of Poland. Warsaw: Ministry of Infrastructure and Development.

Lizak, P. (2011). Przemiany w przemyśle samochodów osobowych w Polsce w latach zmian systemu gospodarowania [Transformations in car industry in Poland in the years of changes of the economic conditions]. Prace Komisji Geografii Przemysłu Polskiego Towarzystwa Geograficznego [Studies of the Industrial Geography Commission of the Polish Geographical Society], 17, 164-176. 
Nowak, P. (2011). Funkcjonowanie sektora motoryzacyjnego w okresie kryzysu w latach 2008-2009 [The automotive industry in times of economic crisis in years 2008-2009]. Prace Komisji Geografii Przemysłu Polskiego Towarzystwa Geograficznego [Studies of the Industrial Geography Commission of the Polish Geographical Society], 17, 177-186

Rachwał, T. (2010). Struktura przestrzenna i działowa przemysłu Polski na tle Unii Europejskiej $\mathrm{w}$ dwudziestolecie rozpoczęcia procesów transformacji systemowej [Spatial and division structure of Polish industry against the European Union in the twentieth anniversary of the start of the transformation processes]. Prace Komisji Geografii Przemysłu Polskiego Towarzystwa Geograficznego [Studies of the Industrial Geography Commission of the Polish Geographical Society], 16, 105-124.

Stryjakiewicz, T. (2008). GlaxoSmithKline. Regional and local networking in post-communist economy. In: P. Pellenbarg, E. Wever (ed.s). International business geography. Case studies of corporate firms. London: Routledge Taylor and Francis Group, 260-275.

Stryjakiewicz, T. (2009). The old and the new in geographical pattern of the Polish transition. Acta Universitatis Palackianae Olomucensis Facultas Rerum Naturalium. Geographica, 40(1), $5-24$.

Tobolska, A. (2014). Choice of locations by foreign investors: motives for and factors of starting a manufacturing activity (the example of selected factories in Poland). Prace Komisji Geografii Przemysłu Polskiego Towarzystwa Geograficznego [Studies of the Industrial Geography Commission of the Polish Geographical Society], 25, 230-250.

Wiedermann, K. (2006). Czynniki i skutki rozwoju przemysłu motoryzacyjnego w skali lokalnej i regionalnej na przykładzie województwa śląskiego [Factors and effects of the automotive industry development in a local and regional scale on the example of the Silesian Voivodeship.]. Praca doktorska w Instytucie Geografii i Gospodarki Przestrzennej Uniwersytetu Jagiellońskiego.

Wojtyra, B., Grudzień, Ł. (2017). Rozwój przemysłu piwowarskiego w Polsce w okresie tzw. piwnej rewolucji w latach 2011-2016 [The Development of the Beer Industry in Poland During "Craft Beer Revolution" (2011-2016)]. Prace Komisji Geografii Przemysłu Polskiego Towarzystwa Geograficznego [Studies of the Industrial Geography Commission of the Polish Geographical Society], 31(1), 52-67.

Bolesław Domański, professor. Research interests of professor Bolesław Domański include: local and regional development and policy including the EU cohesion policy, post-socialist transformation, economic restructuring of industrial and peripheral regions, the impact of foreign direct investment on regional development, delocalisation of economic activities, industrial restructuring, urban regeneration.

\title{
Address:
}

\author{
Jagiellonian University \\ Institute of Geography and Spatial Management \\ ul. Gronostajowa 7, 30-387 Kraków, Poland \\ boleslaw.domanski@uj.edu.pl
}

Krzysztof Gwosdz, professor. Research interests of professor Krzysztof Gwosdz are focused on issues of local and regional development, foreign direct investment, social and economic problems of urban areas and restructuring and regeneration of old industrial regions.

\section{Address:}

Jagiellonian University

Institute of Geography and Spatial Management

ul. Gronostajowa 7, 30-387 Kraków, Poland

e-mail: krzysztof.gwosdz@uj.edu.pl 